\title{
PENGUATAN KOMPETENSI MGMP BIOLOGI SIDOARJO DALAM MATERI PEMBELAJARAN VIRUS HIV
}

\author{
Hanna Tabita Hasianna Silitonga ${ }^{1}$, Hebert Adrianto ${ }^{2}$, Iman Pasu Marganda Hadiarto Purba ${ }^{3}$ \\ ${ }^{1,2)}$ Program Studi Kedokteran, Fakultas Kedokteran, Universitas Ciputra Surabaya, ${ }^{3)}$ Program Studi Pendidikan \\ Kewarganegaraan, Fakultas Ilmu Sosial dan Hukum, Universitas Negeri Surabaya \\ e-mail: hanna.silitonga@ciputra.ac.id
}

\begin{abstract}
Abstrak
Permasalahan yang MGMP Biologi Sidoarjo hadapi adalah dibutuhkannya penguatan materi untuk beberapa topik pelajaran. Salah satunya adalah kompetensi yang harus dikuasai oleh siswa SMA kelas 10 yaitu mampu melakukan kampanye tentang bahaya virus dalam kehidupan terutama HIV/AIDS dengan menggunakan beragam media informasi. Siswa diharapkan mampu untuk menjelaskan proses perkembangbiakan virus, penyebaran dan cara mencegahnya. Selain itu, di kelas 11, siswa diharapkan mampu untuk melakukan kampanye kelainan dalam sistem imun termasuk penyakit HIV/AIDS yang menyerang sistem kekebalan tubuh, dalam berbagai bentuk media informasi. Oleh sebab itu, solusi yang ditawarkan kepada MGMP Biologi Sidoarjo ini adalah penguatan kompetensi guru tentang pengantar dan virus HIV. Metode pelaksanaannya adalah pelatihan dan pendampingan menggunakan metode daring, pendampingan penulisan artikel. Metode penilaian dilakukan dengan pre test dan post test serta wawancara. Para guru merasa kegiatan ini sangat bermanfaat karena diingatkan kembali dan mendapat pemahaman lebih mendalam untuk diajarkan ke siswanya. Selain itu, terdapat perubahan sikap peserta akan ODHA dan mengurangi stigma sosial terhadap ODHA. Para guru juga diminta untuk menghasilkan artikel hasil dari pelatihan dan dipublikasikan secara online.
\end{abstract}

Kata Kunci: Penguatan, Kompetensi, Guru Biologi, Virus, HIV, Metode Daring

\begin{abstract}
The problem that MGMP Biologi Sidoarjo faces was the need to strengthen the material for several subject topics. One of them was the competency that must be mastered by high school students in grade 10, namely being able to campaign about the dangers of viruses in life, especially HIV/AIDS and using various information media. Students were expected to be able to explain the process of virus replication, spread and how to prevent it. In addition, in 11th grade, students were expected to be able to campaign for abnormalities in the immune system including HIV/AIDS disease that attacks the immune system, in various forms of information media. Therefore, the solution offered to MGMP Biologi Sidoarjo was strengthening the teacher's commutence about the introduction and hiv virus. The method of implementation was training and mentoring using online methods and article writing assistance. The assessment method was carried out with pre test and post test as well as interview. Teachers found this activity very rewarding because they were reminded and had a deeper understanding to teach their students. In addition, there was a change in participants' attitudes towards ODHA and reduced social stigma towards ODHA. Teachers were also asked to produce articles resulting from training and published online.
\end{abstract}

Keywords: Strengthening, Competence, Biology Teachers, Viruses, HIV, Online Methods 


\section{PENDAHULUAN}

Penyakit HIV/AIDS adalah salah satu pandemi yang melanda dunia dan masih membutuhkan upaya pencegahan dan pengendalian dari segala sektor. Di Indonesia, dari profil kesehatan Indonesia 2019, jumlah kasus baru HIV pada tahun 2019 adalah sebesar 50.282 orang yaitu 32.443 laki-laki dan 17.839 perempuan (Kementerian Kesehatan Republik Indonesia, 2020). Dari data yang sama, didapatkan jumlah kasus HIV di Provinsi Jawa Timur adalah sebesar 8935 orang dengan jumlah terbesar di rentang umur 25-49 tahun (Kementerian Kesehatan Republik Indonesia, 2020). Mengingat masa inkubasi yang lama dari virus ini, yang dapat mencapai 10-15 tahun maka kemungkinan faktor risiko penularan dapat terjadi di masa remaja.

Berbagai upaya dilakukan untuk mencegah penularan virus ini, termasuk dengan memasukkan materi ini ke dalam kurikulum pembelajaran SMA. Demikian juga dengan sekolah dimana para guru MGMP berada. MGMP (Musyawarah Guru Mata Pelajaran) Guru Biologi Sidoarjo adalah wadah guru biologi di sekolah wilayah Sidoarjo baik sekolah negeri dan swasta. MGMP Guru Biologi Sidoarjo ini beranggotakan 92 orang guru. Permasalahan yang MGMP hadapi adalah dibutuhkannya penguatan materi untuk beberapa topik pelajaran. Salah satunya adalah kompetensi yang harus dikuasai oleh siswa SMA kelas 10 yaitu mampu melakukan kampanye tentang bahaya virus dalam kehidupan terutama HIV/AIDS dnegan menggunakan beragam media informasi. Siswa diharapkan mampu untuk menjelaskan proses perkembangbiakan virus, penyebaran dan cara mencegahnya. Selain itu, di kelas 11, siswa diharapkan mampu untuk melakukan kampanye kelainan dalam sistem imun termasuk penyakit HIV/AIDS yang menyerang sistem kekebalan tubuh, dalam berbagai bentuk media informasi.

Oleh sebab itu, solusi yang ditawarkan kepada MGMP Biologi Sidoarjo ini adalah penguatan komeptensi guru tentang pengantar virus seperti struktur virus, replikasi virus, cara penyebaran virus, pencegahan virus dan juga secara spesifik topik tentang virus HIV. Harapannya melalui penguatan ini, para guru diingatkan kembali dan mendapat pemahaman lebih mendalam untuk diajarkan ke murid-muridnya. Selain itu terdapat perubahan sikap peserta akan ODHA dan mengurangi stigma sosial terhadap ODHA.

\section{METODE}

Metode yang digunakan dalam pengabdian masyarakat ini adalah pelatihan dan pendampingan peserta MGMP Biologi Sidoarjo.

\section{Pelatihan}

Situasi pandemi COVID-19 membuat segala bentuk pembelajaran dan pelatihan dilakukan secara daring. Pada pengabdian masyarakat ini, pelatihan untuk para guru dilakukan menggunakan aplikasi Zoom. Pelatihan ini dibagi ke dalam dua sesi. Sesi pertama membahas tentang Pengantar Virus yang terdiri tiga topik yaitu struktur dan komponen virus, reproduksi/replikasi virus dan transmisi/penyebaran virus. Sesi kedua membahas mengenai Virus HIV (Human Immunodeficiency Virus) yang terdiri dari enam topik yaitu karakteristik virus, transmisi/penularan, gejala dan tanda, diagnosis, pengobatan dan pencegahan. Dalam topik pencegahan juga dibahas mengenai dampak sosial dan stigma yang berhubungan dengan virus HIV. Pada topik ini, juga diundang narasumber Orang Dengan HIV/AIDS (ODHA) yang adalah ibu rumah tangga. Kesaksian dari ODHA ini diharapkan dapat lebih memberi gambaran dan menyentuh para guru sehingga semakin memahami perihal pencegahan dan penularan HIV/AIDS. Kesaksian ODHA juga diharapkan dapat mengubah persepsi para peserta dan mengurangi stigma terhadap ODHA. 


\section{Pendampingan Peserta}

Selain mendapatkan pelatihan, para guru juga dimasukkan ke dalam Grup Whatsapp ${ }^{\mathrm{TM}}$. Hal ini bertujuan untuk mendampingi para peserta agar pengetahuan yang didapatkan dapat diperbaharui dan diskusi setelah pelatihan dapat terus berlanjut. Berbagai informasi juga dibagikan di dalam grup ini untuk memancing diskusi di antara peserta.

\section{Metode Penilaian}

Hasil yang diharapkan dari pengabdian masyarakat ini adalah semakin dalamnya pengetahuan guru biologi mengenai topik virus dan HIV. Oleh sebab itu metode penilaian yang digunakan adalah pre-test dan post-test. Pre-test diberikan sebelum peserta mengikuti pelatihan yang diadakan oleh tim pelaksana. Setelah itu, dilakukan pendampingan melalui grup Whatsapp ${ }^{\mathrm{TM}}$. Post-test diberikan kepada peserta di akhir pengabdian masyrakat. Tujuan dari penilaian ini adalah untuk melihat peningkatan pengetahuan peserta tetang topik pelatihan, yang ditunjukkan dari perubahan nilai pre-test dan post-test. Soal yang diberikan dalam pre dan post test adalah 5 soal tentang pengantar HIV dan 5 soal tentang virus HIV. Baik pre-test dan post-test diberikan dalam bentuk google form.

Selain meningkatnya pengetahuan, harapan dari program ini adalah meningkatnya sikap positif para peserta terhadap ODHA sehingga mampu mengurangi stigma yang terdapat di masyarakat terhadap ODHA. Hal ini diperoleh secara kualitatif dengan menanyakan pengalaman peserta berdiskusi langsung dengan ODHA.

Penguatan kompetensi para peserta juga dilihat dari kemampuan peserta untuk menghasilkan karya artikel tulisan mengenai topik pelatihan. Tulisan peserta ini akan akan dipublikasikan pada media elektronik sekolah agar dapat dibaca lebih banyak orang termasuk siswa.

\section{HASIL DAN PEMBAHASAN}

Peserta dari pengabdian masyarakat ini adalah sebanyak lima orang guru yang nantinya akan menjadi kader untuk mengajarkan kepada sesama guru di MGMP Biologi Sidoarjo. Asal sekolah dari para peserta beragam yaitu dari SMA Kemala Bhayangkari 4 Waru, SMA Katolik Untung Suropati Sidoarjo, SMA Muhammadiyah 4 Porong, SMAN 1 Taman Sidoarjo, SMAN 2 Sidoarjo.
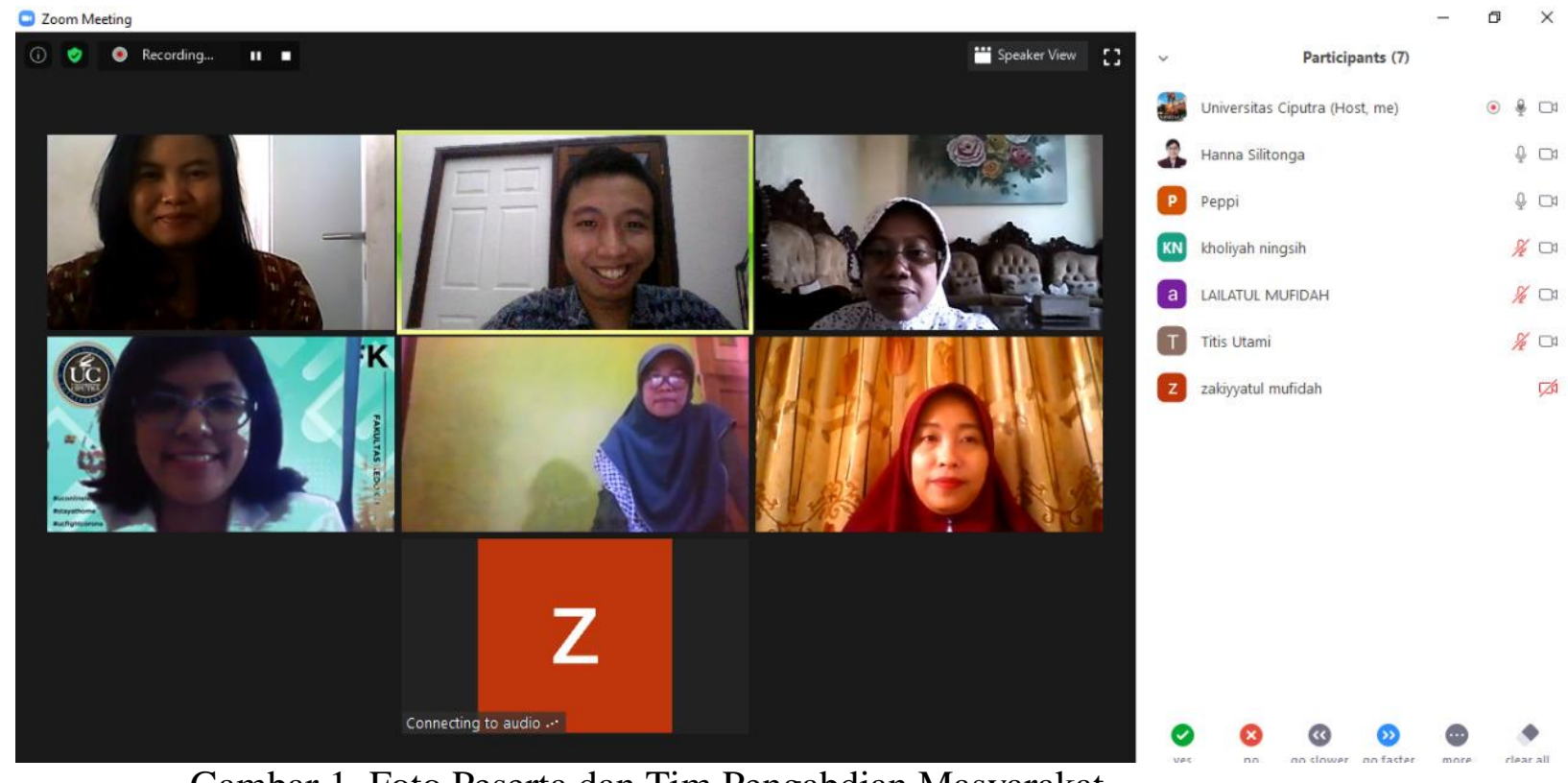

Gambar 1. Foto Peserta dan Tim Pengabdian Masyarakat 


\section{Peningkatan Pengetahuan}

Hasil pre-test dari para peserta dapat dilihat dari tabel 1. Sebelum kegiatan pengabdian masyarakat, para peserta mampu menjawab benar soal pengantar virus dengan rata-rata 2.6 dari lima pertanyaan. Untuk pertanyaan mengenai HIV, para peserta dapat menjawab ratarata 3.6 dari lima pertanyaan. Setelah mendapatkan pelatihan dan pendampingan, terdapat peningkatan jumlah jawaban benar dari peserta, yang dapat dilihat dari tabel 2. Hasil post test menunjukkan ada peningkatan rata-rata jawaban benar yaitu 4.6 dari lima pertanyaan pengantara virus dan 4.4 untuk lima pertanyaan materi virus HIV. Peningkatan pengetahuan antara pre dan post test dapat dilihat dari gambar 2.

Tabel 1. Sebaran Jawaban Pre-test

\begin{tabular}{|l|l|c|c|c|c|}
\hline No & Pertanyaan & \multicolumn{3}{|c|}{ Benar } & \multicolumn{2}{|c|}{ Salah } \\
\cline { 3 - 5 } & & $\mathrm{n}$ & $\%$ & $\mathrm{n}$ & $\%$ \\
\hline 1 & Manakah yang termasuk sifat dari virus? & 5 & $100 \%$ & 0 & 0 \\
\hline 2 & $\begin{array}{l}\text { Di bawah ini manakah yang merupakan pernyataan yang benar } \\
\text { mengenai susunan tubuh virus? }\end{array}$ & 4 & $80 \%$ & 1 & $20 \%$ \\
\hline 3 & $\begin{array}{l}\text { Manakah bagian tubuh virus yang mengandung RNA atau } \\
\text { DNA? }\end{array}$ & 1 & $20 \%$ & 4 & $80 \%$ \\
\hline 4 & $\begin{array}{l}\text { Disebut apakah replikasi virus yang diakhiri dengan matinya } \\
\text { sel inang? }\end{array}$ & 2 & $40 \%$ & 3 & $60 \%$ \\
\hline 5 & $\begin{array}{l}\text { Manakah yang bukan termasuk cara penularan kontak tidak } \\
\text { langsung? }\end{array}$ & 1 & $20 \%$ & 4 & $80 \%$ \\
\hline & Rata-rata & 2.6 & & 2.4 & \\
\hline 6 & Berasal dari famili apakah virus HIV? & 5 & $100 \%$ & 0 & 0 \\
\hline 7 & Manakah yang termasuk penularan HIV? & 4 & $80 \%$ & 1 & $20 \%$ \\
\hline 8 & Untuk melihat apakah tes darah dalam pemeriksaan HIV ? & 3 & $60 \%$ & 2 & $40 \%$ \\
\hline 9 & Apakah yang dimaksud dengan window period dalam HIV? & 3 & $60 \%$ & 2 & $40 \%$ \\
\hline 10 & Manakah yang termasuk mekanisme obat HIV? & 3 & $60 \%$ & 2 & $40 \%$ \\
\hline & Rata-rata & 3.6 & & 1.4 & \\
\hline
\end{tabular}

Tabel 2. Sebaran Jawaban Post-Test

\begin{tabular}{|l|l|c|c|c|c|}
\hline No & Pertanyaan & \multicolumn{3}{|c|}{ Benar } & \multicolumn{2}{|c|}{ Salah } \\
\cline { 3 - 5 } & & $\mathrm{n}$ & $\%$ & $\mathrm{n}$ & $\%$ \\
\hline 1 & Manakah yang termasuk sifat dari virus? & 5 & $100 \%$ & 0 & 0 \\
\hline 2 & $\begin{array}{l}\text { Di bawah ini manakah yang merupakan pernyataan yang benar } \\
\text { mengenai susunan tubuh virus? }\end{array}$ & 5 & $100 \%$ & 0 & 0 \\
\hline 3 & $\begin{array}{l}\text { Manakah bagian tubuh virus yang mengandung RNA atau } \\
\text { DNA? }\end{array}$ & 4 & $80 \%$ & 1 & $20 \%$ \\
\hline 4 & $\begin{array}{l}\text { Disebut apakah replikasi virus yang diakhiri dengan matinya } \\
\text { sel inang? }\end{array}$ & 5 & $100 \%$ & 0 & 0 \\
\hline 5 & $\begin{array}{l}\text { Manakah yang bukan termasuk cara penularan kontak tidak } \\
\text { langsung? }\end{array}$ & 4 & $80 \%$ & 1 & $20 \%$ \\
\hline & Rata-rata & 4.6 & & 0.4 & \\
\hline 6 & Berasal dari famili apakah virus HIV? & 5 & $100 \%$ & 0 & 0 \\
\hline 7 & Manakah yang termasuk penularan HIV? & 5 & $100 \%$ & 0 & 0 \\
\hline 8 & Untuk melihat apakah tes darah dalam pemeriksaan HIV ? & 4 & $80 \%$ & 1 & $20 \%$ \\
\hline 9 & Apakah yang dimaksud dengan window period dalam HIV? & 4 & $80 \%$ & 1 & $20 \%$ \\
\hline 10 & Manakah yang termasuk mekanisme obat HIV? & 4 & $80 \%$ & 1 & $20 \%$ \\
\hline & Rata-rata & 4.4 & & 0.6 & \\
\hline
\end{tabular}




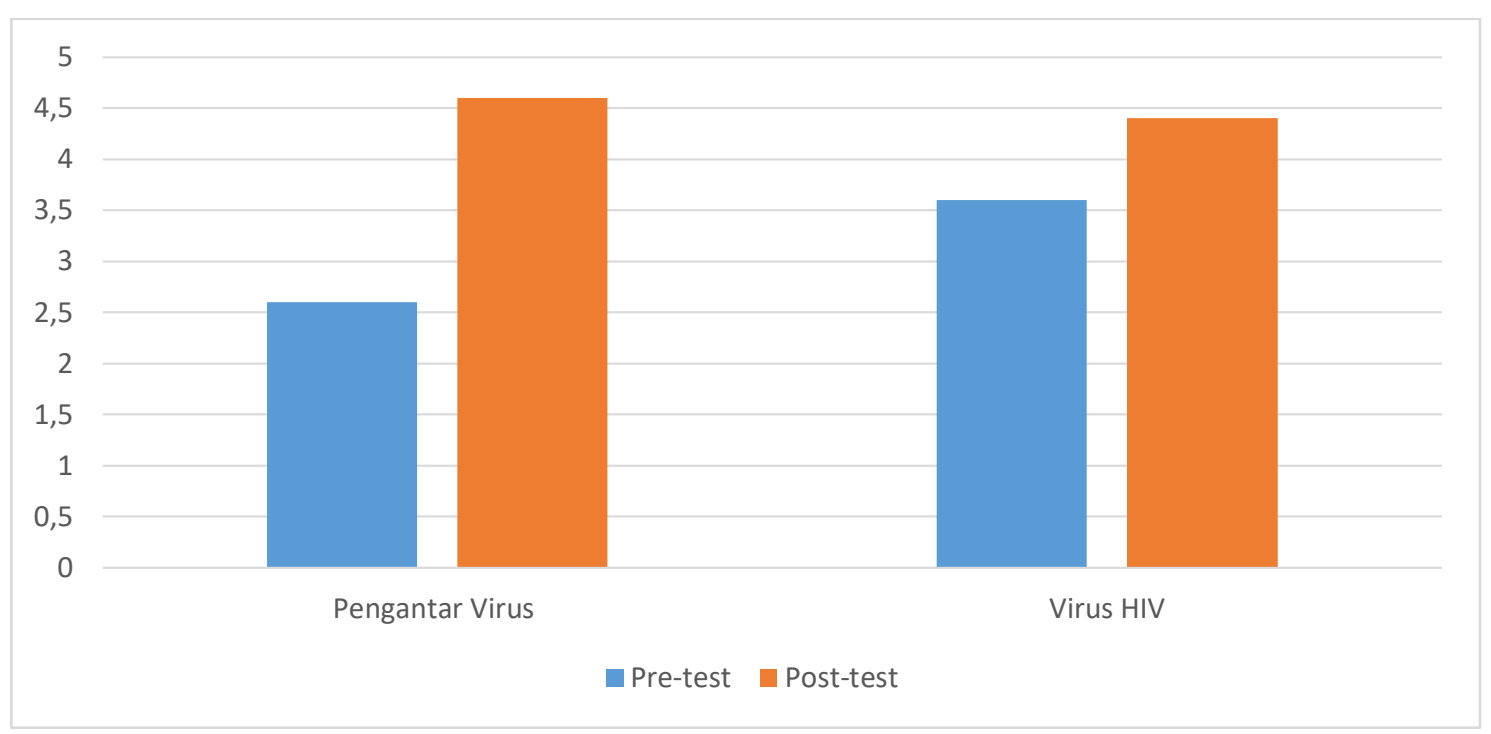

Gambar 2. Grafik Peningkatan Rata-rata Pengetahuan Peserta

\section{Perubahan sikap peserta terhadap ODHA}

Data tentang perubahan sikap peserta terhadap ODHA diperoleh secara kualitatif dengan cara wawancara pengalaman para peserta berdiskusi dengan ODHA. Semua peserta baru pertama kali bertemu dan mendengarkan pengalamanan dari ODHA secara langsung. Beberapa pengalaman yang mereka alami adalah rasa kagum, terharu dan lebih mensyukuri kondisi mereka. Semua peserta menyadari bahwa tidak semua ODHA tertular karena perilaku berisiko seperti penggunaan jarum suntik NAPZA secara bergantian, ataupun berganti-ganti pasangan. Penularan dapat juga terjadi pada ibu rumah tangga yang memiliki pasangan atau suami yang berisiko. Kondisi ini bahkaan bisa ditularkan kepada bayi yang ada di dalam kandungan ibu yang terkena HIV, sehingga bayi atau anak juga menjadi Anak Dengan HIV/AIDS (ADHA). Hal ini membuat para peserta semakin memahami pentingnya pencegahan HIV/AIDS dan tidak melakukan stigma atau diskriminasi kepada ODHA. Hal ini terlihat dari pembicaraan peserta yang dikutip oleh tim:

"Tak terasa air mata menetes mendengar cerita Ibu S terbawa dengan kisahnya"

"Terimakasih..ilmunya bagus banget tadi yang HIV ... langsung dari ODH..."

"Yes, real membuat kita wajib banyak terus bersyukur...."

\section{Penulisan Artikel oleh peserta}

Salah satu target dari pengabdian masyarakat ini adalah meningkatkan kompetensi guru mengenai materi pengantar virus dan virus HIV dan mampu mendiseminasikannya melalui berbagai media informasi. Salah satu peserta telah menulis artikel mengenai topik pelatihan dan melakukan publikasi di aplikasi sekolahnya. Dalam artikelnya, peserta menuliskan pentingnya pengetahuan yang ia dapat dan betapa bermanfaatnya kegiatan pengabdian masyarakat yang dilakukan. 


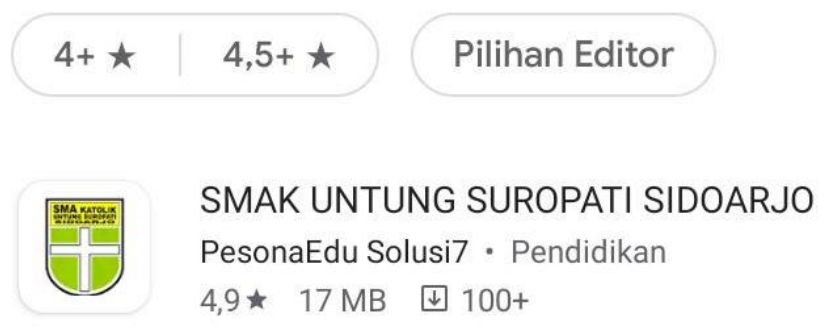

Gambar 3. Aplikasi Pembelajaran Sekolah Tempat Artikel Diterbitkan

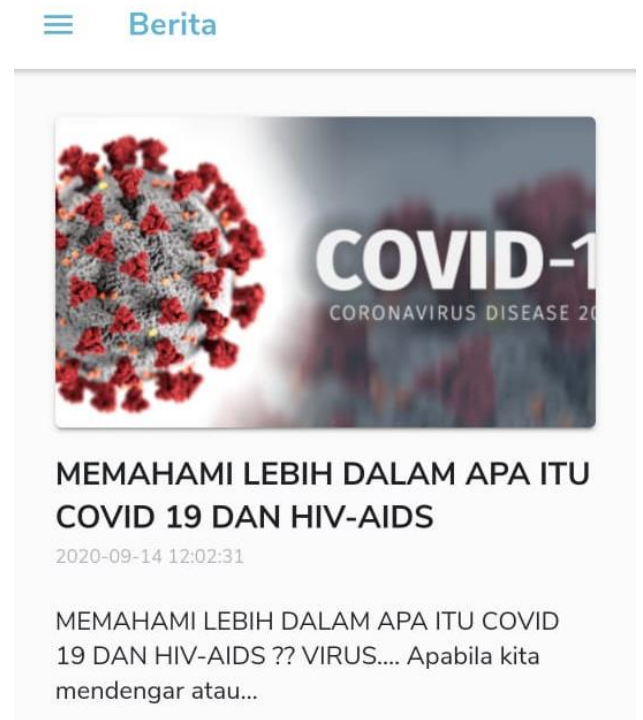

Gambar 4. Tulisan salah satu peserta pelatihan

Dalam situasi pembatasan aktivitas dan sosial berskala besar, maka pembelajaran jarak jauh menjadi hal yang lumrah dilakukan akhir-akhir ini. Sesuai dengan panduan pembelajaran jarak jauh dari Kementerian Pendidikan dan Kebudayaan, prinsip pembelajaran jarak jauh adalah tidak membahayakan baik pengajar dan pihak yang belajar dan realistis yang artinya pencapaian memungkinkan untuk dicapai meskipun daring (Kemendikbud, 2020). Dalam pengabdian masyarakat ini, memilih untuk menggunakan pembelajaran jarak jauh secara daring karena mempertimbangkan kedua hal tersebut.

Metode daring yang dilakukan dalam pengabdian masyarakat ini adalah menggunakan zoom cloud meeting dan juga whatsapp ${ }^{\text {TM }}$ group. Dari hasil pre dan post test, dapat dilihat ada peningkatan pengetahuan dan juga perubahan sikap dari para peserta guru. Hal ini sesuai dengan hasil evaluasi program guru pembelajar dimana ditemukan baik metode pembelajaran full daring ataupun kombinasi dapat meningkatkan kapasitas peserta guru (Awaluddin, 2018). Selain itu, dari metode pembelajaran daring sangat relevan dengan kondisi saat ini.

Selain menggunakan zoom cloud meeting, pada pengabdian masyarakat ini juga menggunakan aplikasi whatsapp group. Beberapa sekolah juga menggunakan aplikasi ini sebagai alat komunikasi instan untuk berkomunikasi dengan sesama teman dan guru mereka (Talan \& Gulsecen, 2019). Segala informasi dapat disampaikan dan diterima dengan cepat oleh para peserta yang bergabung di group tersebut. Selain itu, kelebihan whatsapp group adalah fitur yang mudah untuk digunakan dan merupakan aplikasi yang sudah sering 
digunakan dalam kehidupan sehari-hari sehingga para peserta tidak memerlukan pelatihan khusus untuk menggunakannya. Penggunaan media sosial ini sudah banyak digunakan baik dalam penyuluhan kesehatan, pelatihan, sarana komunikasi (Kholisotin, Prasetyo, \& Agustin, 2019; Sukrillah, Ratnamulyani, \& Kusumadinata, 2017).

Perubahan sikap terhadap ODHA yang dialami para peserta guru terutama karena mendengarkan kesaksian dari ODHA langsung. Umumnya, penyakit HIV dikaitkan dengan kutukan dan perbuatan yang melakukan, padahal terinfeksi HIV dapat terjadi pada orangorang yang tidak melakukan perbuatan asusila misalnya ibu rumah tangga. Ibu rumah tangga yang telah menerima kondisinya dan mendapat pengetahuan yang cukup, maka akan menjadi berdaya dan mampu menjadi agen yang mengedukasi masyarakat dalam mencegah perilaku berisiko HIV/AIDS (Silitonga, 2018). Perubahan sikap ini sangat penting karena guru berperan besar dalam mempengaruhi tindakan pencegahan HIV dari para siswa. Penelitian Manafe dkk menunjukkan bahwa terdapat hubungan antara peran dan sikap guru terhadap tindakan pencegahan HIV dari para siswanya (Manafe, Kandou, \& Posangi, 2014). Dalam teori reasoned action, perilaku seseorang dipengaruhi oleh sikap dan niatnya terhadap sesuatu, sedangkan sikap dipengaruhi oleh kepercayaan dan evaluasinya terhadap sesuatu (Glanz, Rimer, \& Viswanath, 2008). Oleh sebab itu, ketika persepsi para guru berubah terhadap ODHA, kemungkinan besar perilakunya juga berubah terhadap ODHA. Hal ini penting dalam menurunkan stigma dan diskriminasi institusi pendidikan terhadap ODHA dan ADHA.

Peningkatan pengetahuan dan perubahan sikap dari para guru diharapkan dapat bermanfaat bagi guru biologi dalam menyampaikan materi terkait virus dan HIV kepada para muridnya. Dalam mempercepat pencapaian kompetensi siswa untuk mampu memahami materi ini, para guru juga dapat menggunakan berbagai media komunikasi (Haerana, Salfiantini, \& Ridwan, 2015; Ifroh \& Ayubi, 2018; Saputra et al., 2011). Salah satu dari media itu adalah media visual yang dapat dibaca secara massal. Oleh sebab itu, para peserta didorong untuk menghasilkan artikel yang dipublikasikan secara online atau offline dan dibaca oleh seluruh penghuni sekolah. Pada pengabdian masyarakat ini, artikel yang ditulis guru dipublikasikan dalam aplikasi sekolah dan dapat dibaca oleh semua siswa dan guru.

\section{SIMPULAN}

Secara umum, kegiatan pengabdian masyarakat ini berjalan dengan lancar. Hasil pre dan post test menunjukkan terdapat peningkatan pengetahuan dari para peserta, selain itu hasil wawancara menunjukkan perubahan sikap dari para peserta tentang ODHA. Kemampuan peserta untuk menulis artikel dan dipublikasikan juga menunjukkan peningkatan kompetensi dari para peserta guru. Kompetensi ini sangat berguna untuk membantu para guru mengajar topik materi biologi tentang pengantar virus dan juga virus HIV, serta membantu para siswa untuk tidak melakukan stigma dan diskriminasi terhadap ODHA.

\section{SARAN}

Masa pandemi COVID-19 membuat terbatasnya ruang dan gerak tim pelaksana dalam menyelenggarakan pengabdian masyarakat ini karena adanya himbauan untuk melakukan social distancing. Akan tetapi, dari seluruh keterbatasan itu, kegiatan pengabdian masyarakat ini tetap dapat berjalan sesuai dengan harapan. Saran untuk kedepannya adalah pelatihan membuat media audiovisual untuk topik-topik biologi sehingga membantu para siswa memahami materi walaupun menggunakan sistem daring. 


\section{UCAPAN TERIMA KASIH}

Ucapan terimakasih diberikan kepada DRPM Kementerian Riset, Teknologi, dan Pendidikan Tinggi yang telah memberikan hibah PKMS MGMP Biologi Sidoarjo. Terimakasih juga untuk LPPM dan Fakultas Kedokteran Universitas Ciputra Surabaya serta para peserta MGMP atas dukungan dan partisipasinya untuk kegiatan ini.

\section{DAFTAR PUSTAKA}

Awaluddin, Y. (2018). Efektivitas Program Guru Pembelajar Dalam Peningkatan Kompetensi Guru Ips Smp Dengan Moda Daring Murni Dan Daring Kombinasi: Studi Evaluatif Dan Komparatif. Jurnal Pendidikan Dan Kebudayaan, 3(1), 1. http://doi.org/10.24832/jpnk.v3i1.717

Glanz, K., Rimer, B. K., \& Viswanath, K. (2008). Health Behaviour and Health Education. Health Education (Vol. 63). http://doi.org/10.1016/S0033-3506(49)81524-1

Haerana, B. T., Salfiantini, \& Ridwan, M. (2015). Peningkatan Pengetahuan Komprehensif HIV dan AIDS Melalui Peer Group. Jurnal MKMI, 132-138.

Ifroh, R. H., \& Ayubi, D. (2018). Efektivitas Kombinasi Media Audiovisual Aku Bangga Aku Tahu Dan Diskusi Kelompok Dalam Upaya Meningkatkan Pengetahuan Remaja Tentang HIV-AIDS. Perilaku Dan Promosi Kesehatan, 1(1), 32-43.

Kemendikbud. Panduan: Pembelajaran Jarak Jauh - bersama hadapi korona, Kementrian Pendidikan dan Kebudayaan 4 (2020). Retrieved from https://bersamahadapikorona.kemdikbud.go.id/panduan-pembelajaran-jarak-jauh/

Kementerian Kesehatan Republik Indonesia. (2020). Data dan Informasi kesehatan indonesia 2019. Profil Kesehatan Indonesia, 8(9), 1-213. http://doi.org/10.1017/CBO9781107415324.004

Kholisotin, Prasetyo, A. D., \& Agustin, Y. D. (2019). Pengaruh Penyuluhan Berbasis Video Whatsapp Tentang Persalinan Terhadap Pengetahuan dan Sikap Ibu Hamil Trimester III di Puskesmas Klabang Kabupaten Bondowoso. The Indonesian Journal of Health Science, 11(2). http://doi.org/10.1017/CBO9781107415324.004

Manafe, L. A., Kandou, G., \& Posangi, J. (2014). Hubungan antara Pengetahuan, Sikap, Peran Guru, Media Informasi (Internet) dan Peran Teman Sebaya dengan Tindakan Pencegahan HIV / AIDS pada Siswa di SMA Negeri 4 Manado. JIKMU, Suplemen, 4(4), 644-655.

Saputra, N., Studi, P., Keperawatan, I., Kedokteran, F., Ilmu, D. A. N., Islam, U., \& Syarif, N. (2011). AIDS DENGAN METODE CURAH PENDAPAT DAN CERAMAH MENGGUNAKAN MEDIA AUDIO VISUAL TERHADAP PENGETAHUAN SISWA SMAN 4 TANGERANG SELATAN.

Silitonga, H. T. H. (2018). Behavior of PLWHA IDU and Housewives in Preventing HIV/ AIDS Transmission. Jurnal Kedokteran Mulawarman, 5(2), 11-22.

Sukrillah, A., Ratnamulyani, I., \& Kusumadinata, A. (2017). Pemanfaatan Media Sosial Melalui Whatsapp Group FEI sebagai Sarana Komunikasi. Jurnal Komunikatio, 3(2). http://doi.org/10.24036/ld.v2i2.3525

Talan, T., \& Gulsecen, S. (2019). The effect of a flipped classroom on students' achievements, academic engagement and satisfaction levels. Turkish Online Journal of Distance Education, 20(4), 31-60. http://doi.org/10.17718/TOJDE.640503 